\title{
Variability in selected Properties of Crude Oil - Polluted Soils of Izombe, Northern Niger Delta, Nigeria
}

\author{
Ihem E. E.", Osuji G. E., Onweremadu E. U., Uzoho B. U., Nkwopara U. N., Ahukemere C. M., \\ Onwudike S. O., Ndukwu B. N., Osisi A. S., Okoli N. H.
}

Department of Soil Science and Technology, Federal University of Technology, Owerri, Imo State, Nigeria

Email address:

eeihem2000@yahoo.com (Ihem E. E.)

\section{To cite this article:}

Ihem E. E., Osuji G. E., Onweremadu E. U., Uzoho B. U., Nkwopara U. N., Ahukemere C. M., Onwudike S. O., Ndukwu B. N., Osisi A. S., Okoli N. H.. Variability in selected Properties of Crude Oil - Polluted Soils of Izombe, Northern Niger Delta, Nigeria. Agriculture, Forestry and Fisheries. Special Issue: Environment and Applied Science Management in a Changing Global Climate. Vol. 4, No. 3-1, 2015, pp. 29-33. doi: 10.11648/j.aff.s.2015040301.15

\begin{abstract}
We investigated the variability in some soil properties influenced by crude oil-polluted soils of Izombe in Northern Niger Delta of Nigeria in 2013. A free survey technique was used in the field sampling with nine profile pits dug in the site. Routine soil analysis was conducted on some physico-chemical properties including heavy metals. Soil data were subjected to analysis of variance using proc mix-model of SAS software at $\mathrm{P} \leq 0.05$. Results showed that soils were dark grayish brown to red in colour. Soils of the studied area were also deep $(>100 \mathrm{~cm})$, well drained and having percent sands $(>80 \%)$. Soils from crude oil-polluted site showed lower $\mathrm{pH}(<3.92)$ than the unpolluted soils with $\mathrm{pH}>4.00$. Soil organic matter, C:N ratio, TEA and percent Al. Sat, were appreciably higher in soils affected by crude oil pollution. Unaffected soils by crude oil pollution exhibited higher TN, P, TEB and B.Sat. Heavy metal concentrations in the polluted sites were relatively higher than their unaffected counterparts and were significant $(p \leq 0.05)$. Further studies should be conducted on some other properties and in owner-managed farm establishments.
\end{abstract}

Keywords: Variability, Crude Oil, Soil Quality, Tropical Soils

\section{Introduction}

Other than agricultural practices, oil exploration is a major economic activity in the Niger Delta areas of Nigeria. This has resulted in the pollution and contamination of agricultural lands for farming (terrestrial and aquatic environment). Soils and water polluted with crude oil poses a serious threat to living organisms within the environment. Crude oil contains heavy metals that may be phytotoxic to plants and injurious to animals [1]. It could also cause acidification of the soils [2]. Apart from factors such as previous farming practices, parent materials, topography, crude oil pollution results to variations in soil properties. However, variations of soil physical and chemical properties, nutrient levels and water content occur at field scale [3]. Crude oil reduces the fertility of the soil by making plant essential nutrients unavailable. [4] reported that sites polluted with crude oil contain metals such as Barium (Ba), Cadmium (Cd), Chromium (Cr), Lead ( $\mathrm{Pb}$ ), Nickel (Ni), Copper $(\mathrm{Cu})$ and Zinc $(\mathrm{Zn})$ and their mobility depends on the concentration and soil properties. Farmers are now amending and remediating soils affected by crude oil with the hope of optimizing agricultural outputs across fields. These attempts are made to regenerate soil fertility in the study area which has been lowered by the influence of crude oil spillage, using sewage sludge [5], water hyacinth residues [6]. Municipal solid wastes [7]), cassava peel, cattle dung and poultry droppings [8]. These efforts improved quality for increased productivity. Similarly study has been conducted in some other locations outside the study site. However, studies in this region have shown that most of the valuable lands in the studied site are either temporarily or permanently lost to oil exploration activities in form of flow-station, disposal pits for burying oil and land covered with spilled oil [9. Based on this, we investigated the influence of crude oil pollution on the variability of selected soil properties.

\section{Materials and Methods}

A field experiment was conducted at oil exploration sites during April, 2009 to March, 2010 at Izombe, Owerri - 
Nigeria. The experimental site is located within Northern Niger Delta region of Nigeria (Latitudes $5^{0} 20^{1}$ and $5^{0} 41^{1} \mathrm{~N}$ and longitudes $6^{0} 37^{1}$ and $\left.6^{0} 49^{1} \mathrm{E}\right)$. Soils of the area are derived from coastal plain sands and are dominated by ultisols. The site belongs to the lowland area of Nigeria, with a humid tropical climate with mean annual rainfall of $2250 \mathrm{~mm}$ and mean annual temperature range of $26-31^{\circ} \mathrm{C}$. The main socio-economic activity of the study site is arable farming, hunting and oil exploration activities. Land preparation includes slash and burn system with conventional tillage system.

\subsection{Field Studies}

A free survey technique was used to locate the study site. Nine (9) pedons of about $200 \mathrm{~cm}$ depths were dug covering polluted sites (7) pedons and unpolluted sites (2) pedons. After horizon delineation soil samples were taken from the component horizons; air-dried and made to pass through a $2 \mathrm{~mm}$ sieve prior to laboratory analysis.

\subsection{Laboratory Analysis}

Particle size distribution was estimated by hydrometer method [10].

Bulk density was determined by core procedure, [11]. The soil was transferred from the sample holders of core sampler to a container and placed in an oven at $105^{\circ} \mathrm{C}$ and dried to a constant weight. The weight of soil was recorded and bulk density calculated by the formula of [12] as follows:

$$
\text { Bulk density }=\frac{\text { Ovendryweightsoil }}{\text { samplevolume }}
$$

Soil $\mathrm{pH}$ was determined electrometrically in a soil solution ratio of $1: 2.5$ [13].

Total nitrogen was estimated using the modified microkjeldahl digestion method [14] and sodium copper sulphate catalyst mixture [15].

Organic matter was measured as described by [16] Nelson and Somnars, (1982). Organic matter was calculated by multiplying organic carbon by [17], factor" of 1.724 .

Available phosphorus was determined by using the molybdemum blue colour Bray II method [18].

Exchangeable Bases were determined from Ammonuim acetate $\left(\mathrm{NH}^{4} \mathrm{OAC}\right)$ leachates of the soil [19].

Exchangeable Acidity was determined by leaching the soil with $1 \mathrm{NKCl}$ and titrates with $0.05 \mathrm{NaOH}$ solutions [20]. Effective cation exchange capacity was estimated by the summation of the total exchangeable bases (TEB) and exchangeable acidity (TEA). It is expressed in Cmol/kg Soil [21].

Heavy metal concentrations were measured individually with atomic absorption spectrometer (AAS) after wet digestion with concentrated $\mathrm{H}_{2} \mathrm{SO}_{4}$ for $\mathrm{Cr}$, mixture of $\mathrm{HNO}_{3}$ and $\mathrm{HCL}$ for $\mathrm{Hg}$, and $\mathrm{Cd}$ and $\mathrm{HNO}_{3}$ for $\mathrm{Ni}, \mathrm{V}$ and $\mathrm{Pb}$ respectively [22].

Statistical Analysis

Data were subjected to analysis of variance (ANOVA) using the Statistical Analysis System (SAS) version 2008 model.

\section{Results and Discussion}

The results of the morphological properties of the soil studied are summarized in Table 1.

Table 1. Morphological properties of Studied Soils

\begin{tabular}{|c|c|c|c|c|c|}
\hline Horizon & Depth (cm) & Colour & Structure & Drainage & Boundary \\
\hline Ap & $0-23$ & $2.5 \mathrm{YR}^{4} / 2$ & W gr & ewd & Clear \\
\hline $\mathrm{AB}$ & $23-86$ & $2.5 \mathrm{YR}^{5} / 2$ & M gr & ed & Smooth \\
\hline $\mathrm{Bt}_{1}$ & $86-130$ & $2.5 \mathrm{YR}^{4} / 9$ & $\mathrm{M} \mathrm{sb}$ & ed & Gradual \\
\hline $\mathrm{Bt}_{2}$ & $130-195$ & $2.5 \mathrm{YR}^{4} / 8$ & $\mathrm{Si} \mathrm{b}$ & wd & Diffuse \\
\hline
\end{tabular}

$\mathrm{W}$ gr $=$ Weak granular, $\mathrm{m}$ gr $=$ Medium granular, $\mathrm{m} \mathrm{sb}=$ Medium sub-angular block, $\mathrm{Si} \mathrm{b}=\mathrm{Sub}-$ irregular blocky, ewd $=$ Excessively well drained, ed $=$ Excessively drained, wd = well drained.

Table 2. Some physical properties of the Studied Soils

\begin{tabular}{|c|c|c|c|c|c|c|}
\hline Location & Depth (cm) & Sand (\%) & Silt (\%) & Clay (\%) & $\mathrm{BD}\left(\mathrm{g} / \mathrm{cm}^{3}\right)$ & SCR \\
\hline \multirow[t]{3}{*}{ Polluted soils } & $0-23$ & 80.23 & 7.80 & 8.17 & 1.42 & 0.95 \\
\hline & $23-86$ & 84.05 & 7.65 & 8.39 & 1.44 & 0.91 \\
\hline & $130-195$ & 80.34 & 9.40 & 9.61 & 1.57 & 0.98 \\
\hline SED & & 2.94 & 1.21 & 0.85 & 0.03 & 0.33 \\
\hline$P$ value & & $0.5433^{\mathrm{NS}}$ & $0.4292^{\mathrm{NS}}$ & $0.0973^{\mathrm{NS}}$ & $<0.0001$ & $0.4808^{\mathrm{NS}}$ \\
\hline \multirow{3}{*}{ Unpolluted soils } & $23-86$ & 80.16 & 7.50 & 12.33 & 1.45 & 0.61 \\
\hline & $86-130$ & 77.67 & 7.83 & 14.50 & 1.49 & 0.54 \\
\hline & $130-195$ & 79.33 & 10.33 & 10.67 & 1.55 & 0.97 \\
\hline SED & & 5.56 & 4.11 & 3.16 & 0.08 & 0.74 \\
\hline$P$ value & & $0.076^{\mathrm{NS}}$ & $0.8397^{\mathrm{NS}}$ & $0.6289^{\mathrm{NS}}$ & $0.2919^{\mathrm{NS}}$ & $0.3993^{\mathrm{NS}}$ \\
\hline
\end{tabular}


Generally, the soils studied were deep $(>100 \mathrm{~cm})$, well drained and with cleared horizons differentiation. The deep pedons with distinct horizonation is an indication that the soils have undergone pronounced weathering [23]. Results of soil physical properties are shown in Tab. 2. Results showed that soils in the studied site were sandy $(>80 \%)$. No significant difference $(\mathrm{P}<0.05)$ was shown in the percentage sand between polluted and unpolluted soils. Soil texture is an inherent property and may not have been influenced significantly by crude oil pollution in the study area. The bulk density ranged from $1.37-1.57 \mathrm{~g} / \mathrm{cm}^{3}$ with a mean of $1.48 \mathrm{~g} / \mathrm{cm}^{3}$ for polluted soils and $1.47 \mathrm{~g} / \mathrm{cm}^{3}$ for unpolluted soils. There was no particular trend in bulk density distribution among the pedons but with higher values occurring in polluted soils. Crude oil is known to increase bulk density in soils perhaps due to aggregate disintegration. [24] reported that oil spillage increases bulk density due to aggregate disintegration. The chemical properties of the studied soils are presented in Table 3 . The results showed that the soils of the area were acidic, with a mean $\mathrm{pH}$ value of 3.92 in polluted soils and 4.00 in unpolluted soils. The stronger soil reaction of the polluted soils could be attributed to the impact of crude oil pollution. Oil in soils tends to decrease the $\mathrm{pH}$ generally, making it unsuitable for crop production. This situation could be compounded by the high rainfall, leaching which results in washing away of basic cations from the soils and the acidic nature of the parent materials in the studied site. The resultant effect of these may be the preferential removal of basic cations through leaching resulting in the accumulation of exchangeable acidic cations $\left(\mathrm{Al}^{+}\right.$and $\left.\mathrm{H}^{+}\right)$in the soil absorption complex of polluted soils [25]. Higher values of Organic matter $(2.00 \%)$ and $\mathrm{C} / \mathrm{N}$ ration (18.87) in crude oil polluted soils explained presence of carbon in the petroleum hydrocarbon discharged and deposited on the polluted soils during crude oil spillage. This finding is in line with earlier work done by [26] where low organic matter and $\mathrm{C} / \mathrm{N}$ ratio in unpolluted land units confirmed high mineralization process in the organic matter and also due to high temperature and excessive high rainfall which characterize the study area [27]. Values of total nitrogen, phosphorus, ECEC and percent base saturation were consistently lower in polluted soils compared to the unpolluted counterparts, which revealed that crude oil pollution encouraged nutrient elements imbalance as well as phosphorus fixation among other elements [28]. Results of some heavy metals in the site are shown in Table 4.

Table 3. Some Chemical Properties of the Studied Soils

\begin{tabular}{|c|c|c|c|c|c|c|c|}
\hline Location & Depth $(\mathrm{cm})$ & pH (1NKCl) & OM (\%) & TN (\%) & $\mathrm{C} / \mathbf{N}(\%)$ & Av.P (mg/kg) & $\mathrm{Ca}(\mathrm{Cmol} / 100 \mathrm{~g})$ \\
\hline \multirow[t]{6}{*}{ Polluted soils } & $0-23$ & 4.08 & 3.75 & 0.1 & 20.61 & 11.79 & 0.9 \\
\hline & $23-86$ & 3.95 & 1.72 & 0.06 & 16.94 & 7.09 & 0.74 \\
\hline & $86-130$ & 3.89 & 1.51 & 0.05 & 18.53 & 5.02 & 0.93 \\
\hline & $130-195$ & 3.73 & 1.01 & 0.05 & 19.42 & 5.13 & 0.88 \\
\hline & SED & 0.1 & 0.94 & 0.019 & 3.73 & 0.9 & 0.192 \\
\hline & $P$ Value & 0.0114 & 0.0329 & $<0.001$ & 0.7952 & $<0.001$ & 0.123 \\
\hline \multirow[t]{6}{*}{ Unpolluted soils } & $0-23$ & 4.05 & 2.79 & 0.17 & 24.57 & 1.15 & 1.18 \\
\hline & $23-86$ & 4.25 & 1.66 & 0.14 & 19.28 & 9.1 & 1.13 \\
\hline & $86-130$ & 4.11 & 1.39 & 0.13 & 16.96 & 7.87 & 1.74 \\
\hline & $130-195$ & 3.6 & 1.21 & 0.12 & 22.69 & 7.57 & 0.83 \\
\hline & SED & 0.39 & 0.59 & 0.02 & 0.1446 & 0.873 & 1.01 \\
\hline & $P$ value & 0.5568 & 0.1375 & 0.1666 & 0.9528 & 0.9703 & 0.8599 \\
\hline
\end{tabular}

Table 3. continued

\begin{tabular}{|c|c|c|c|c|c|c|c|c|}
\hline Location & $\mathrm{Mg}(\mathrm{Cmol} / 100 \mathrm{~g})$ & K (Cmol/100g) & $\mathrm{Na}(\mathrm{Cmol} / \mathbf{1 0 0 g})$ & $\mathrm{H}^{+}(\mathrm{Cmol} / \mathbf{1 0 0 g})$ & $\mathbf{A l}^{3+}$ & ECEC & Al.sat & B.sat \\
\hline \multirow[t]{5}{*}{ Polluted soils } & 0.57 & 0.07 & 0.64 & 1.23 & 0.89 & 4.11 & 24.24 & 50.81 \\
\hline & 0.63 & 0.057 & 0.46 & 1.32 & 0.96 & 4.07 & 24.41 & 46.86 \\
\hline & 0.87 & 0.107 & 0.46 & 1.36 & 0.76 & 4.13 & 23.17 & 45.35 \\
\hline & 0.9 & 0.071 & 0.51 & 1.19 & 0.7 & 4.13 & 22.26 & 50.45 \\
\hline & 0.2147 & 0.036 & 0.16 & 0.316 & 0.07 & 0.33 & 0.406 & 3.87 \\
\hline \multirow[t]{6}{*}{ Unpolluted soils } & 1.09 & 0.18 & 0.64 & 0.57 & 0.62 & 5.96 & 11.04 & 65.54 \\
\hline & 1.05 & 0.15 & 0.46 & 0.88 & 0.69 & 5.98 & 12.78 & 43.99 \\
\hline & 0.93 & 0.18 & 0.46 & 0.51 & 0.55 & 5.13 & 15.32 & 62.4 \\
\hline & 0.67 & 0.23 & 0.51 & 0.48 & 0.45 & 4.76 & 11.92 & 66.03 \\
\hline & 0.087 & 0.16 & 0.16 & 0.08 & 0.09 & 0.59 & 3 & 2.27 \\
\hline & 0.0208 & 0.97 & 0.674 & 0.001 & 0.18 & 0.245 & 0.566 & 0.002 \\
\hline
\end{tabular}

$\mathrm{OM}=$ Organic matter, $\mathrm{TN}=$ Total nitrogen, $\mathrm{C} / \mathrm{N}=$ Carbon-nitrogen ratio, $\mathrm{Av} . \mathrm{P}=$ Available phosphorus, $\mathrm{Ca}=\mathrm{Calcium}, \mathrm{Mg}=\mathrm{Magnesium}, \mathrm{K}=\mathrm{Potassium}, \mathrm{Na}=$ Sodium, $\mathrm{H}=$ Hydrogen, $\mathrm{Al}=$ Aluminum, $\mathrm{ECEC}=$ Effective Cation Exchange Capacity, Al.sat= Aluminium saturation, B.sat= Base saturation. 
Table 4. Some heavy metals concentration in the Studies Site

\begin{tabular}{|c|c|c|c|c|c|c|}
\hline Location & Depth (cm) & Hg (mg/kg) & $\mathrm{Cd}(\mathrm{mg} / \mathrm{kg})$ & $\mathrm{V}(\mathrm{mg} / \mathrm{kg})$ & $\mathrm{Cr}(\mathrm{mg} / \mathrm{kg})$ & $\mathrm{Pb}(\mathrm{mg} / \mathrm{kg})$ \\
\hline \multirow[t]{4}{*}{ Polluted soils } & $0-23$ & 0.04 & 7.52 & 0.09 & 7.25 & 5.35 \\
\hline & $23-86$ & 0.04 & 6.74 & 0.94 & 7.41 & 4.66 \\
\hline & $86-130$ & 0.02 & 5.84 & 0.61 & 6.99 & 4.55 \\
\hline & $130-195$ & 0.02 & 5.65 & 0.59 & 6.95 & 4.50 \\
\hline SED & & 0.003 & 1.03 & 0.22 & 1.12 & 0.45 \\
\hline$P$ value & & $<0.003$ & 0.2665 & 0.0066 & 0.9741 & 0.2173 \\
\hline \multirow{3}{*}{ Unpolluted soils } & $23-86$ & 0.01 & 3.20 & 0.29 & 3.81 & 4.67 \\
\hline & $86-130$ & 0.02 & 2.38 & 0.13 & 3.10 & 1.70 \\
\hline & $130-195$ & 0.01 & 2.97 & 0.10 & 3.48 & 1.29 \\
\hline SED & & 0.005 & 0.06 & 0.05 & 0.08 & 0.29 \\
\hline$P$ value & & 0.4850 & $<0.001$ & 0.0027 & 0.005 & 0.001 \\
\hline
\end{tabular}

$\mathrm{Hg}=$ Mecury, $\mathrm{Cd}=$ Cadmium, $\mathrm{V}=$ Vanaduim, $\mathrm{Cr}=$ Chromium, $\mathrm{Pb}=$ Lead

Higher values of heavy metals $(\mathrm{Hg}, \mathrm{Cd}, \mathrm{V}, \mathrm{Cr}$, and $\mathrm{Pb})$ were observed in polluted soils compared to the unpolluted soils. [29] reported that crude oil contains heavy metals and possibly added to the soil during oil spillage but below their critical levels for crop production [30].

\section{Conclusion}

The study revealed that the study soils were deep and well drained with high proportion of percent sand. Oil exploration activities had a meager effect on particle sizes, influences soil properties by increasing the values of $\mathrm{Om}, \mathrm{C} / \mathrm{N}$ ratio, $\% \mathrm{H}$ and $\mathrm{Al}$ saturation. Soil $\mathrm{pH}, \mathrm{N}, \mathrm{P}, \% \mathrm{~B}$. sat are decreased as influenced by crude oil pollution. Concentration of heavy metals in the polluted soils were compounded by crude oil pollution and showed a significant difference $(\mathrm{P}<0.05)$. The study indicated that crude oil exhibited a negative influence on soil productivity in the Niger Delta region of Nigeria, hence required improved agronomic practices and crude oil remediation for optimum agricultural production.

\section{References}

[1] FEPA (1991). "Guidelines and Standards for Environmental pollution control in Nigeria" Federal Environmental protection Agency.

[2] Iwegbue, C.M.A., Isirimah, N.O., Igwe, C. and Williams, E.S. (2006). Characteristic levels of heavy metals in soil profiles of automobile mechanic waste dumps in Nigeria. Environmentalist 26:123-128.

[3] Osuji, I.C and Onajake, C.M (2004).The Ebocha oil spillage II.Fate of associated heavy metals six months after.Agricultural Journal and Environmental Assessment Management (AJEAM - RAGEE) VOL. 9: 78 - 87.

[4] Mbagwu, J.S.C., Oti, N.N., Agbin, N.N. and Udom, B.E (2001).Effects of Sewage Sludge application on selected soil properties and yield of Maize and Bambara Groundnut. AgroScience 2: $37-43$.

[5] Oguike, P.C and Mbagwu, J.S.C (2001). Effects of Water hyacinth residues on chemical properties and productivity of degraded tropical soils. Agro-science 2: 44 - 51.
[6] Mbagwu, J.S.C and Piccolo, A. (1990).Carbon, nitrogen and phosphorus concentration on aggregate of organic waste amended soils.Biol. Wastes.31: 97 - 11.

[7] Onweremadu, E.U. (2007c). Characterization of degraded ultisol amended with cassava peel, cattle dung and poultry droppings in Southeastern Nigeria. J. plant Sci. 2(5): $564-569$.

[8] Ekoko, G. (1997). Save our land, Delta State University Press, Asaba.

[9] Gee, G.W. and Or, D. (2002). Particle size analysis. In: methods of soil analysis, Dane, J.H and G.C. Topp (Eds) Part 4. physical methods. Soil sci. Amer. book series 5, ASA and SSSA, Madison, Wisconsin 255-293.

[10] Black, G.R. and Hartge, K.H. (1986).Bulk density. In: Klute, A. (ed) methods of soil analysis, Part 1Physical and mineralogical methods $2^{\text {nd }}$ ed. Agronomy No. 9. ASASSSA, Madison. WI, pp $363-375$.

[11] Black, G.R. and Hartge, K.H. (1986).Bulk density. In: Klute, A. (ed) methods of soil analysis, Part 1Physical and mineralogical methods $2^{\text {nd }}$ ed. Agronomy No. 9. ASASSSA, Madison. WI, pp 363 - 375.

[12] Hendershot, W.H.; Laland, H. and Duquette, M. (1993).Soil reaction and exchangeable acidity. In: soil sampling and methods of analysis.

[13] Bremner, J.M. (1996). Nitrogen - Total. In: Sparks, D.J (ed) Methods of soils Analysis, Part 3, chemical heavy metals in a spent oil polluted typicpaleudult. Southeastern Nigeria. Int. J. Agric. And Rural Development 11(2): 77 - 81).

[14] Bremner, J.M. and Yeomans, J. C (1988). Laboratory techniques in J.R. Wilson (ed) Advances in Nitrogen cycling in Agricultural ecosystems. C.A.B. intWilling for, England.

[15] Nelson, D.W. and Sommers, L.E. (1982).Total carbon, organic carbon and organic matter. In: page A.L., Miller, R.H. and Kenney, D.R. (eds). Methods of soil analysis, part 2. Ameri. Soc. Agron: Madison, Wisconsin 539-579.

[16] Olson, S.R. and Sommers, L.E (1982).Phosphorus. In: Page A.L., Miller, R.H and Keeuey, D.R (eds). Methods of Soil Analysis, part 2 Amer. Soc. Agron, Madison Wisconsin 403-430.

[17] Thomas, G.W. (1982). Exchangeable bases. In: Methods of Soil analysis, part 2. Page A.L., Miller, R.H and Keeney, D.R (eds). Pp. 159 - 165 (American Society of agronomy Madison, W.J 
[18] McLean, E.V. (1982). Aluminium. In: page, A. L. soil analysis part 2, American Society of Agronomy, Madison, W.I. pp. 978-998.

[19] Bruce, A.M. and Whiteside, P.J. (1984).Introduction to atomic absorption Spectrophotometer $3^{\text {rd }}$ ed. PyeUnicam Limited England.

[20] Onweremmadu, E.U., Oti, N.N and Uzoho, B.U. (2005). Evaluation of selected soil chemical parameters in two crude oil-spilled sites in Southeastern Nigeria. Journal of Sustainable Tropical Agric. Research, 16: 33 - 42.

[21] Foth, H.D. (1984). Fundamental of Soil Science John Willey and sons, New York. 359pp.

[22] Akamigbo, F.O.R. (1993). Causes, impact and implication of gully erosion in Southeastern Nigeria. Paper presented at the $29^{\text {th }}$ Annual Conference of Agric. Soc. of Nigeria, held at Federal University of Agric. Umudike, Abia State, Oct. 31Nov.3, 1993
[23] McOliver, K. (1984). Introduction to Petroleum Geology. England 465pp.

[24] Omeke, J.O., Eshette, E.T., Ihem, E.E., Etwuoku, A. and Nnaji, G.U. (2009).Characteristics and fertility status of arable soils proximal to selected gas flaring sites in Delta State Region of Nigeria. Int. Journal of Agric.And Rural Dev. Vol. (12) $34-$ 39.

[25] Foth, H.D. (1984). Fundamental of Soil Science John Willey and sons, New York. 359pp.

[26] Akinlabi, O.A. (1981). Effect of oil industrial activities in the North Apoi oil field. Federal Ministry of Housing and Environment., Vol. 5 Nig. 4-10.

[27] FEPA (1991). "Guidelines and Standards for Environmental pollution control in Nigeria" Federal Environmental protection Agency. 